\title{
Soil microbial and nutrient dynamics influenced by irrigation-induced salinity and sewage sludge incorporation in sandy - loam textured soil
}

\author{
Ankush ${ }^{1}{ }^{1} *$, Ram Prakash ${ }^{1}$, Rakesh Kumar ${ }^{2}$, Vikram Singh ${ }^{3}$, Harender ${ }^{3}$, and Vijay K. Singh ${ }^{4}$ \\ ${ }^{1}$ Department of Soil Science, ${ }^{2}$ Department of Microbiology, ${ }^{3}$ Department of Agronomy, \\ CCS HAU, Haryana - 125 001, India \\ ${ }^{4}$ Department of Natural Resource Management, Birsa Agricultural University, Ranchi, Jharkhand - 834006, India
}

Received July 26, 2020; accepted October 19, 2020

\begin{abstract}
The use of sewage sludge in agriculture is known to be environmentally friendly as it is a practical way of recycling municipal waste. A short-term experiment was carried out to study the changes in soil chemical and microbiological properties influenced through the addition of sewage sludge along with saline irrigation under a pearl millet-wheat crop rotation. There were three irrigation (canal water $\left(0.35 \mathrm{dS} \mathrm{m}^{-1}\right), 8$ and $10 \mathrm{dS} \mathrm{m}^{-1}$ electrical conductivity saline water) and five fertilizer treatments (control- $\mathrm{F}_{1}$, sewage sludge $\left(5 \mathrm{t} \mathrm{ha}^{-1}\right)-\mathrm{F}_{2}$, sewage sludge $\left(5 \mathrm{t} \mathrm{ha}^{-1}\right)$ $+50 \%$ recommended dose of fertilizer $(\mathrm{RDF})-\mathrm{F}_{3}$, sewage sludge $\left(5 \mathrm{t} \mathrm{ha}^{-1}\right)+75 \%$ RDF-F 4 and RDF-F ). The results showed that soil organic carbon, and available nitrogen, and phosphorus were reduced significantly under saline conditions but there was an increase in available potassium with the increasing salinity levels of the irrigation water. A significant reduction in soil microbial biomass carbon and enzyme activities was caused by 8 and $10 \mathrm{dS} \mathrm{m}^{-1}$ as compared to $0.35 \mathrm{dS} \mathrm{m}^{-1}$ at different growth stages of crops. Treatment $\mathrm{F}_{4}$ attained the highest soil microbial activity at each crop growth stage by a significant margin among all of the fertilizer treatments, which is associated with a substantial build-up of organic carbon and available NPK in the soil. Soil microbial activities followed a particular trend: at 35 and 75 days after sowing $>$ harvest $>$ sowing in pearl millet and wheat, respectively. Sewage sludge dumping is a major problem in India, and the present study suggests that by applying sewage sludge, soil biological health is improved; therefore its use in agriculture is recommended to farmers.

Keyw ords: sewage sludge, saline irrigation, soil, microbial biomass carbon, enzyme activity
\end{abstract}

*Corresponding author e-mail: ankushdhanda@hau.ac.in

\section{INTRODUCTION}

The rapidly increasing human population and urbanization have led to the production of domestic and industrial waste in large amounts (Sharma and Dhaliwal, 2019). Sewage sludge is a semi-solid byproduct which is obtained from wastewater treatment plants and treated as waste in developing countries like India where it remains deposited near municipal solid waste treatment plants. It poses a great environmental threat when no management strategy is adopted for proper sludge disposal. Despite the widespread assumption that sewage sludge (SS) is a problem, its management as a valuable organic resource has become essential for sustainability. Moreover, SS is a potential source of nutrients that may be applied to agricultural lands (Bourioug et al., 2017). It may be used as an organic fertilizer that produces a favourable crop yield and it may even replace mineral fertilizers but only when it does not pose any risk to soil quality and human health (Ahmed et al., 2010). Its excessive use can also cause heavy metal toxicity in soils and plants (McGrath et al., 2000). Sewage sludge is relatively inexpensive in comparison to mineral fertilizers and has a higher amount of organic matter and plant nutrients, particularly nitrogen, phosphorus, potassium, calcium, and micronutrients (Jezierska-Tys and Frąc, 2009). It improves the physical, chemical, and biological properties of the soil (Aranyos et al., 2016; Meena et al., 2016).

(C) 2020 Institute of Agrophysics, Polish Academy of Sciences 
Enzymes play a vital role in nutrient cycling in the soil and their activity is considered to be a valuable index of soil fertility (Wang et al., 2008). For instance, soil microbial biomass carbon $(\mathrm{MBC})$ is an important indicator of the living content of organic matter while dehydrogenase activity is an important indicator of active microbial activity in soil that facilitates the oxidation of organic matter (Maurya et al., 2011). Furthermore, alkaline phosphatase hydrolyses the ester bond (C-O-P) of inorganic material and releases inorganic phosphorus (Huang et al., 2011). Soil urease is an extracellular enzyme, which facilitates the hydrolysis and transformation of the urea type substrate. The addition of any organic material including SS or mineral fertilizer increases microbial activity in the soil (Meena et al., 2016). Moreover, soil enzyme activity is also associated with other soil properties, microbial cells, vegetation type, fertilizer rates, and climate, etc. (Jingjing et al., 2015; Wang et al., 2016; Srinivasarao et al., 2018).

The pearl millet-wheat cropping system is the second most prominent and widely adopted cropping system in Haryana (India) after the rice-wheat system (Yadav et al., 2012). Before the introduction of the canal system in Haryana, people used to implement open-well irrigation and the salinity problem was low due to shallow depth (Datta and Jong, 2002). After canal system development, continuous groundwater exploitation increased due to the planting of heavy irrigation duty crops (Kumar et al., 2007). Thus, poor water management practices have led to the situation of waterlogging, salinization, and the accumulation of salts on the soil surface due to the 'cup-shaped' topography of Haryana, which makes it more likely to be affected by salinity (Bhat et al., 2017). Salinity is the most common soil problem in arid and semi-arid conditions, it causes the exhibition of negative effects concerning soil physicochemical (Kumawat et al., 2011) and biological properties which can seriously diminish soil health (Singh et al., 2018a). Soil biological processes are essential for their ecological functions and for the maintenance of biodiversity in the soil. Microbial enzyme activities and MBC are negatively correlated with salinity (Singh et al., 2018a) this may be due to a change in the osmotic potential of the soil-water phase, specific ion effects, or ion imbalance (Meena et al., 2018). On account of the shortage of water and unpredictability of rainfall, farmers often have to irrigate crops with poor quality waters thereby further exhausting water resources, the end result is likely to diminish soil health further.

In India, farmers are often hesitant to make use of SS in agriculture because they consider it only as waste without knowing its importance. The incorporation of organic amendments might help in conserving soil organic matter and alleviating salinity effects (Leogrande and Vitti, 2018). Nonetheless, the requirement to increase our level of understanding of the combined use of saline irrigation and SS is imperative. However, the direct and residual effects of SS addition under the pearl millet-wheat system have not been properly studied. Thus, the present study was undertaken to examine the impacts of SS on soil microbial activities at different crop growth stages as well as other chemical properties using saline water irrigation in pearl millet-wheat crop rotation for two consecutive years during the years 2017-19.

\section{MATERIALS AND METHODS}

The present study is a part of a research programme (2013-19) "Evaluation of sewage sludge as a source of NPK for pearl millet-wheat rotation irrigated with saline water". The experiment was carried out at the Soil Research Farm, Chaudhary Charan Singh Haryana Agricultural University (CCS HAU), Hisar over two consecutive years (2017-19), at a latitude of $29^{\circ} 8^{\prime} \mathrm{N}$ and a longitude of $75^{\circ} 70^{\prime} \mathrm{E}$. The site is located in a semi-arid, sub-tropics region, and is situated at an elevation of $215 \mathrm{~m}$ above the mean sea level. The experimental soil was sandy loam in texture. Initially, the soil was low in organic carbon $(0.31 \%)$ and available nitrogen (110 $\left.\mathrm{kg} \mathrm{ha}^{-1}\right)$; and medium in available phosphorus $\left(16.1 \mathrm{~kg} \mathrm{ha}^{-1}\right)$ and available potassium $\left(290 \mathrm{~kg} \mathrm{ha}^{-1}\right)$. The soil was found to be alkaline on testing ( $\mathrm{pH} 8.25)$ and had soil EC $0.37 \mathrm{dS}$ $\mathrm{m}^{-1}$. The DTPA - extractable trace metals ( $\mathrm{Fe}, \mathrm{Mn}, \mathrm{Zn}, \mathrm{Cu}$, $\mathrm{Pb}, \mathrm{Cd}, \mathrm{Cr}, \mathrm{Ni}$ and $\mathrm{Co}$ ) in soil were $2.31,4.40,1.37,0.83$, $1.47,0.06,0.15,0.25$ and $0.04 \mathrm{mg} \mathrm{kg}^{-1}$, respectively. The experiment was laid out in a factorial randomly blocked design with three replications. The experiment consisted of three irrigation levels, i.e. canal water $0.35 \mathrm{dS} \mathrm{m}^{-1}\left(\mathrm{I}_{1}\right), 8 \mathrm{dS}$ $\mathrm{m}^{-1}\left(\mathrm{I}_{2}\right)$ and $10 \mathrm{dS} \mathrm{m}^{-1} \mathrm{EC}$ saline water $\left(\mathrm{I}_{3}\right)$; and five fertilization levels, i.e. control (no fertilizers $\left.-\mathrm{F}_{1}\right)$, $\mathrm{SS}\left(5 \mathrm{t} \mathrm{ha}^{-1}-\mathrm{F}_{2}\right)$, SS $\left(5 \mathrm{tha}^{-1}+50 \%\right.$ of the recommended dose of fertilizers (RDF) $\left.\mathrm{F}_{3}\right)$, SS $\left(5 \mathrm{tha}^{-1}+75 \% \mathrm{RDF} \mathrm{F}_{4}\right)$ and RDF $\left(\mathrm{F}_{5}\right)$. The amount of nutrients (NPK) was broadcasted through the addition of urea, diammonium phosphate, and muriate of potash, respectively. A half dose of nitrogen $(\mathrm{N})$ and a full portion of phosphorus $(\mathrm{P})$ and potassium $(\mathrm{K})$ were incorporated at the sowing time of crops and the remaining $\mathrm{N}$ dose was applied after the 1st irrigation. Pearl millet and wheat varieties, i.e. HHB 226 and WH 1105 were sown for the experiment, respectively. Sowing was performed manually with the assistance of a handled plough. The remaining procedures were carried out according to package practice adopted in Haryana.

The sewage sludge was collected from the municipal solid waste treatment plant located at HAU farm, Hisar, and incorporated into the field during the Rabi season of the experimental period. Before the analysis, the SS sample was air-dried, ground, and passed through a $2 \mathrm{~mm}$ sieve. The SS and water suspension ratios were assumed to be 1:5 in the case of the determination of $\mathrm{pH}$ and $\mathrm{EC}$ and thereafter, the standard methods were adopted (Richard, 1954). Digestion (with the di-acid mixture) is the main step followed thereafter, standard methods were adopted for analysis purposes (Antil et al., 2002). 
The main irrigation source in Haryana is the canal and also tube-well water and there is reliable regime for canal water irrigation. For pearl millet and wheat crops, about 2-3 and 4-5 irrigations were applied depending on the rainfall during the cropping season, respectively. The borewell groundwater at the site is saline in nature. During the irrigation intervals of crops, salinity levels of water with a desirable EC ( 8 and $\left.10 \mathrm{dS} \mathrm{m}^{-1}\right)$ were prepared by repeatedly mixing bore-well water with canal water. Water samples were taken at the time of irrigation and standard methods were adopted to calculate the levels of carbonates $\left(\mathrm{CO}_{3}{ }^{2-}\right)$, bicarbonates $\left(\mathrm{HCO}_{3}^{2-}\right)$, chlorides $\left(\mathrm{Cl}^{-}\right)$, calcium $\left(\mathrm{Ca}^{2+}\right)$, magnesium $\left(\mathrm{Mg}^{2+}\right)$, sodium $\left(\mathrm{Na}^{+}\right)$, and potassium $\left(\mathrm{K}^{+}\right)$in the water sample (Richard, 1954). Sulphate $\left(\mathrm{SO}_{4}{ }^{2-}\right)$ content was determined using the Chesnin and Yien (1950) method by using $\mathrm{BaCl}_{2}$ and gum acacia solution. $S A R$ is an irrigation water quality parameter and is used as an indicator of the suitability of water for use in agriculture for irrigation purposes. The formula used for calculating SAR (Todd, 1980) is as follows:

$$
S A R=\frac{\mathrm{Na}^{+}}{\sqrt{\frac{\mathrm{Ca}^{2+}+\mathrm{Mg}^{2+}}{2}}} .
$$

The initial soil samples were collected randomly from several field locations in a zig-zag pattern at a soil depth of $0-15 \mathrm{~cm}$ before the pearl millet crop was sown with the aid of a hand auger. A composite sample was ground and passed through a $2 \mathrm{~mm}$ sieve before being placed in a polythene pack for further analysis. For each cropping system, post-harvest soil samples were collected from their respective treated plots at a soil depth of $0-15 \mathrm{~cm}$, and an analysis was carried out. For the estimation of microbial properties, the samples were collected independently in a closed lid jar. Moist soil samples $(0-15 \mathrm{~cm})$ were collected plot-wise at the time of sowing, $35 \mathrm{DAS}$, and at harvest time for pearl millet, for wheat, at sowing, 75 DAS, and at harvest time over the course of the experiment and placed in the fridge. A chemical analysis of the soil samples for texture, $\mathrm{pH}, \mathrm{EC}$, organic carbon, available $\mathrm{N}, \mathrm{P}$, and $\mathrm{K}$ was completed using standard methods as outlined by Antil et al. (2002). Microbial biomass carbon was determined by using the fumigation method $\left(0.5 \mathrm{M} \mathrm{K}_{2} \mathrm{SO}_{4}\right)$ as described by Vance et al. (1987). The dehydrogenase activity in the soil was determined using the method explained by Page et al. (1982). An assay of alkaline phosphatase activity was performed using p-Nitrophenol (PNP) as a standard (Page et al., 1982). Urease activity was determined with the aid of a urea solution and potassium chloride-phenyl mercuric acetate as described by Tabatabai and Bremner (1972).

The site has a continental climate and is located on the outer margins of the southwest monsoon region. The main characteristics of the climate in Hisar are dryness, temperature extremes, and inadequate rainfall. The average annual rainfall is around $429 \mathrm{~mm}$. The mean monthly meteorological data during the cropping seasons (2017-18 and 2018-19) were recorded at the meteorological observatory and are depicted in Fig. 1.

The data collected from the field experiment fitted in a factorial randomized block design were statistically analysed by using the EXCEL and OPSTAT statistical software package developed by the Department of Statistics, CCS Haryana Agricultural University (Sheoran et al., 1998) to run an ANOVA test $(p=0.05)$. The mean values were compared to a test of the level of significance $(p=0.05)$ by calculating their least significant difference (LSD) tests using Rstudio (Version 1.1.463).

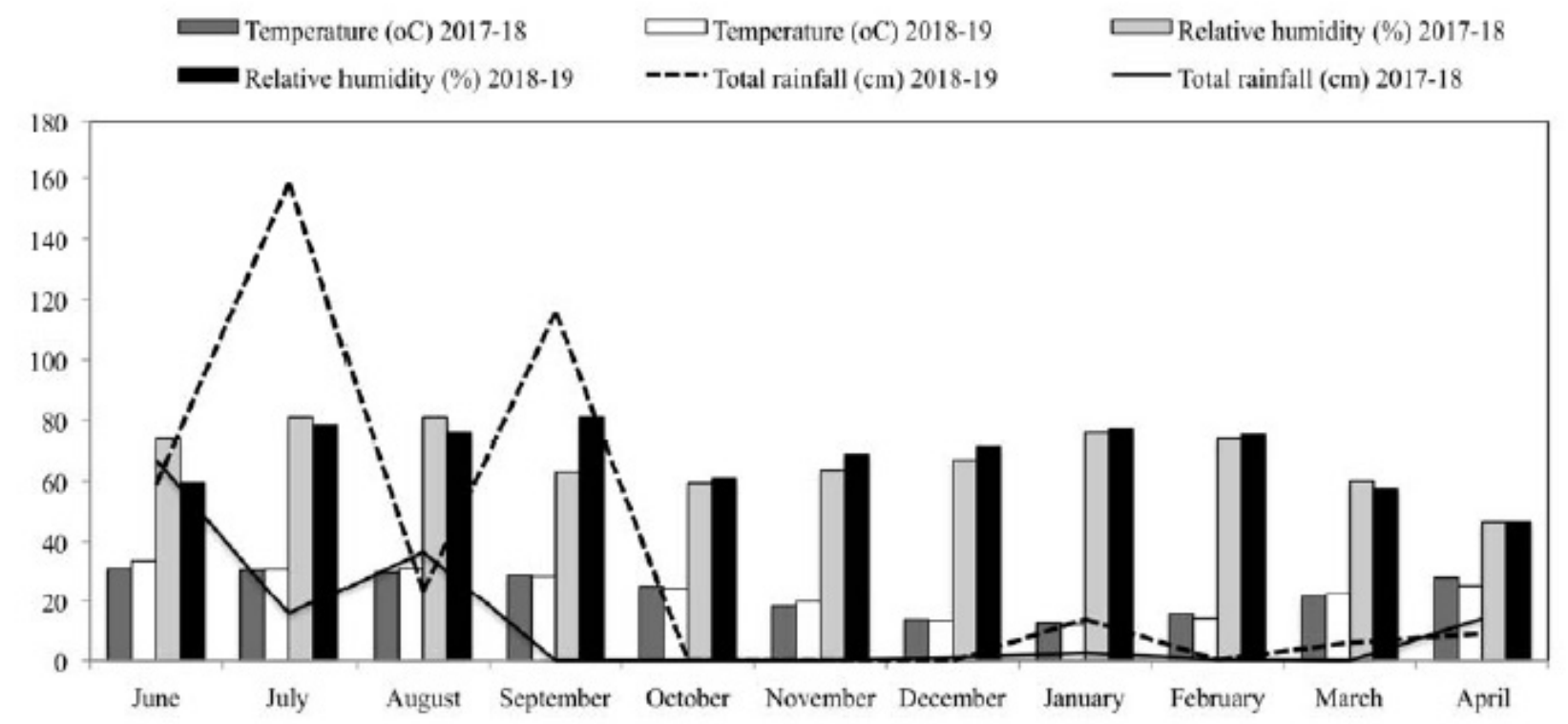

Fig. 1. Mean monthly meteorological data during the cropping seasons (2017-18 and 2018-19). 
Table 1. Chemical composition of sewage sludge (domestic)

\begin{tabular}{|c|c|c|}
\hline Parameter & $\begin{array}{c}\text { Sewage sludge } \\
(\text { Mean } \pm \text { SD })\end{array}$ & $\begin{array}{c}\text { Maximum } \\
\text { permissible } \\
\text { limit } \\
(\mathrm{New} \\
\text { Delhi)* }\end{array}$ \\
\hline $\mathrm{pH}_{(1: 5)}$ & $7.84 \pm 0.57$ & \\
\hline $\mathrm{EC}_{(1: 5)}\left(\mathrm{dS} \mathrm{m}^{-1}\right)$ & $1.45 \pm 0.05$ & \\
\hline Organic carbon (\%) & $25.4 \pm 0.51$ & \\
\hline Nitrogen $(\%)$ & $1.36 \pm 0.05$ & \\
\hline Phosphorus (\%) & $0.87 \pm 0.02$ & \\
\hline Potassium (\%) & $1.40 \pm 0.16$ & \\
\hline \multicolumn{3}{|c|}{ Total metals $\left(\mathrm{mg} \mathrm{kg}^{-1}\right)$} \\
\hline Iron $(\mathrm{Fe})$ & $256 \pm 23.46$ & - \\
\hline Manganese (Mn) & $103 \pm 12.14$ & - \\
\hline Zinc $(\mathrm{Zn})$ & $49.02 \pm 5.30$ & 1200 \\
\hline Copper $(\mathrm{Cu})$ & $11.05 \pm 1.52$ & 300 \\
\hline Lead $(\mathrm{Pb})$ & $28.65 \pm 5.20$ & 100 \\
\hline Cadmium (Cd) & Trace & 5 \\
\hline Chromium (Cr) & $9.90 \pm 0.45$ & 50 \\
\hline Nickel (Ni) & $13.55 \pm 0.11$ & 70 \\
\hline Cobalt (Co) & $2.87 \pm 0.29$ & 5 \\
\hline
\end{tabular}

*Source: CPCB, 2006.

\section{RESULTS}

The SS used throughout the time of experimentation was collected from the University farm where all kinds of domestic waste come to the treatment plant. The chemical composition of SS is presented in Table 1. It had a higher level of organic carbon (25.4\%) and a lower amount of heavy metals, i.e. $\mathrm{Pb}\left(28.65 \mathrm{mg} \mathrm{kg}^{-1}\right)$; $\mathrm{Cd}\left(<1 \mathrm{mg} \mathrm{kg}^{-1}\right)$; $\mathrm{Cr}$ (9.9 $\left.\mathrm{m} \mathrm{kg}^{-1}\right)$; $\mathrm{Ni}\left(13.55 \mathrm{mg} \mathrm{kg}{ }^{-1}\right)$ and $\mathrm{Co}\left(2.87 \mathrm{mg} \mathrm{kg}^{-1}\right)$, which were under the standard permissible limit as per the guidelines of the Central Pollution Control Board (CPCB, 2006). The chemical characteristics of the irrigation water are expressed in Table 2. The saline water used to irrigate the crops was predominantly influenced by chloride ions and had a high $S A R$. Soluble ions in the water increased with the increasing level of salinity. However, the order of soil soluble cations and anions was as follows: $\mathrm{Na}^{+}>\mathrm{Mg}^{2+}$ $>\mathrm{Ca}^{2+}>\mathrm{K}^{+}$and $\mathrm{Cl}^{-}>\mathrm{SO}_{4}{ }^{2-}>\mathrm{HCO}_{3}{ }^{-}$, respectively.

The application of $\mathrm{SS}$ and saline irrigation did not cause any significant difference in soil pH (Table 3 ). Saline irrigation water significantly increased soil EC while SS application made no significant difference. A significantly higher soil EC $\left(1.96 \mathrm{dS} \mathrm{m}^{-1}\right)$ was obtained with $\mathrm{I}_{3}$ followed by $\mathrm{I}_{2}$, i.e. $1.73 \mathrm{dS} \mathrm{m}^{-1}$ and, the lowest soil EC $\left(0.44 \mathrm{dS} \mathrm{m}^{-1}\right)$ was obtained with $\mathrm{I}_{1}$ treatment.

The data regarding organic carbon expressed in Table 3 revealed that soil organic carbon has been significantly affected by the application of SS and saline water irrigation. It was observed that soil organic carbon was significantly reduced under $\mathrm{I}_{2}$ and $\mathrm{I}_{3}$ treatments. The soil organic carbon content was significantly increased with the addition of SS. However, the highest soil carbon content was obtained with $\mathrm{F}_{4}$ being at par with $\mathrm{F}_{3}$ and $\mathrm{F}_{2}$ and above that of $\mathrm{F}_{5}$ and $\mathrm{F}_{1}$.

Based on pooled mean data (Table 3), it was observed that a significantly higher value was obtained for available nitrogen with the $\mathrm{I}_{1}$ treatment, i.e. $116.62 \mathrm{~kg} \mathrm{ha}^{-1}$. Treatments $\mathrm{I}_{2}$ and $\mathrm{I}_{3}$ caused a significant reduction of 11.6 and $13.4 \%$, respectively, as compared to $\mathrm{I}_{1}$. Among various treatments, a significantly higher value for available nitrogen was obtained with $\mathrm{F}_{4}$, i.e. $116.61 \mathrm{~kg} \mathrm{ha}^{-1}$; being at

Table 2. Chemical characteristics of irrigation water

\begin{tabular}{|c|c|c|c|}
\hline \multirow{2}{*}{ Parameter } & \multicolumn{3}{|c|}{ Treatments $($ Mean \pm SD) } \\
\hline & Canal & $8 \mathrm{dS} \mathrm{m}^{-1}$ & $10 \mathrm{dS} \mathrm{m}^{-1}$ \\
\hline $\mathrm{pH}$ & $7.10 \pm 0.30$ & $7.66 \pm 0.55$ & $7.83 \pm 0.57$ \\
\hline $\mathrm{EC}\left(\mathrm{dS} \mathrm{m} \mathrm{m}^{-1}\right)$ & $0.35 \pm 0.01$ & $8.17 \pm 0.31$ & $10.09 \pm 0.38$ \\
\hline \multicolumn{4}{|c|}{ Soluble cations $\left(\mathrm{me} \mathrm{l}^{-1}\right)$} \\
\hline $\mathrm{Na}^{+}$ & $0.71 \pm 0.010$ & $53.8 \pm 1.08$ & $69.15 \pm 1.38$ \\
\hline $\mathrm{K}^{+}$ & $0.09 \pm 0.004$ & $0.35 \pm 0.01$ & $0.40 \pm 0.2$ \\
\hline $\mathrm{Ca}^{2+}$ & $0.98 \pm 0.02$ & $7.50 \pm 0.02$ & $8.45 \pm 0.17$ \\
\hline $\mathrm{Mg}^{2+}$ & $1.65 \pm 0.19$ & $18.5 \pm 2.13$ & $24.04 \pm 2.77$ \\
\hline \multicolumn{4}{|c|}{ Soluble anions $\left(\mathrm{me} \mathrm{l}^{-1}\right)$} \\
\hline $\mathrm{CO}_{3}^{2-}$ & Nil & Nil & Nil \\
\hline $\mathrm{HCO}_{3}^{-}$ & $0.80 \pm 0.06$ & $1.60 \pm 0.12$ & $2.40 \pm 0.17$ \\
\hline $\mathrm{Cl}^{-}$ & $1.35 \pm 0.05$ & $59.6 \pm 2.26$ & $72.8 \pm 2.76$ \\
\hline $\mathrm{SO}_{4}^{2-}$ & $1.20 \pm 0.02$ & $19.2 \pm 0.38$ & $25.27 \pm 0.51$ \\
\hline$S A R$ & $0.62 \pm 0.02$ & $14.9 \pm 0.59$ & $17.15 \pm 0.69$ \\
\hline
\end{tabular}


Table 3. Effect of irrigation-induced salinity and sewage sludge on available nitrogen, phosphorus and potassium in post harvest soil (Pooled mean data of two years (2017-18 and 2018-19))

\begin{tabular}{|c|c|c|c|c|c|c|}
\hline \multirow{2}{*}{ Treatments } & \multirow{2}{*}{$\mathrm{pH}$} & \multirow{2}{*}{$\mathrm{EC}\left(\mathrm{dS} \mathrm{m} \mathrm{m}^{-1}\right)$} & \multirow{2}{*}{$\begin{array}{c}\text { Organic carbon } \\
(\%)\end{array}$} & \multicolumn{3}{|c|}{ Available nutrients $\left(\mathrm{kg} \mathrm{ha}^{-1}\right)$} \\
\hline & & & & Nitrogen & Phosphorus & Potassium \\
\hline \multicolumn{7}{|c|}{ Irrigation levels } \\
\hline $\mathrm{I}_{1}$ & $8.15^{\mathrm{a}}$ & $0.44^{\mathrm{a}}$ & $0.38^{\mathrm{a}}$ & $116.62^{\mathrm{a}}$ & $19.32^{\mathrm{a}}$ & $292.48^{\mathrm{b}}$ \\
\hline $\mathrm{I}_{2}$ & $8.07^{\mathrm{a}}$ & $1.73^{\mathrm{b}}$ & $0.37^{\mathrm{b}}$ & $103.15^{\mathrm{b}}$ & $16.70^{\mathrm{b}}$ & $332.34^{\mathrm{a}}$ \\
\hline $\mathrm{I}_{3}$ & $8.07^{\mathrm{a}}$ & $1.96^{\mathrm{c}}$ & $0.36^{\mathrm{b}}$ & $100.99^{b}$ & $15.77^{\mathrm{b}}$ & $349.39^{\mathrm{a}}$ \\
\hline $\mathrm{SEm} \pm$ & 0.11 & 0.05 & 0.004 & 2.21 & 0.58 & 7.17 \\
\hline \multicolumn{7}{|c|}{ Fertilization levels } \\
\hline $\mathrm{F}_{1}$ & $8.24^{\mathrm{a}}$ & $1.22^{\mathrm{a}}$ & $0.29^{\mathrm{d}}$ & $95.20^{\mathrm{c}}$ & $12.68^{\mathrm{d}}$ & $301.06^{\mathrm{b}}$ \\
\hline $\mathrm{F}_{2}$ & $8.09^{\mathrm{a}}$ & $1.49^{\mathrm{a}}$ & $0.40^{\mathrm{b}}$ & $104.41^{b}$ & $15.88^{\mathrm{c}}$ & $319.54^{\mathrm{ab}}$ \\
\hline $\mathrm{F}_{3}$ & $7.99^{\mathrm{a}}$ & $1.44^{\mathrm{a}}$ & $0.42^{\mathrm{ab}}$ & $106.98^{\mathrm{b}}$ & $19.22^{\mathrm{ab}}$ & $333.36^{\mathrm{a}}$ \\
\hline $\mathrm{F}_{4}$ & $7.94^{\mathrm{a}}$ & $1.41^{\mathrm{a}}$ & $0.43^{\mathrm{a}}$ & $116.61^{\mathrm{a}}$ & $20.81^{\mathrm{a}}$ & $344.98^{\mathrm{a}}$ \\
\hline $\mathrm{F}_{5}$ & $8.22^{\mathrm{a}}$ & $1.31^{\mathrm{a}}$ & $0.32^{\mathrm{c}}$ & $111.38^{\mathrm{ab}}$ & $17.73^{\mathrm{bc}}$ & $324.76^{\mathrm{ab}}$ \\
\hline $\mathrm{SEm} \pm$ & 0.15 & 0.06 & 0.005 & 2.86 & 0.75 & 9.26 \\
\hline Interaction (I x F) & NS & NS & NS & NS & NS & NS \\
\hline
\end{tabular}

$\mathrm{I}_{1}-$ Canal; $\mathrm{I}_{2}-8 \mathrm{dS} \mathrm{m}^{-1} \mathrm{EC}$ saline water and $\mathrm{I}_{3}-10 \mathrm{dS} \mathrm{m}^{-1} \mathrm{EC}$ saline water; $\mathrm{F}_{1}-$ Absolute control (No fertilizer); $\mathrm{F}_{2}-\mathrm{SS}\left(5 \mathrm{t}\right.$ ha $\left.{ }^{-1}\right) ; \mathrm{F}_{3}-$ $\mathrm{SS}\left(5 \mathrm{t} \mathrm{ha}^{-1}\right)+50 \% \mathrm{RDF} ; \mathrm{F}_{4}-\mathrm{SS}\left(5 \mathrm{t} \mathrm{ha}^{-1}\right)+75 \%$ RDF and $\mathrm{F}_{5}-100 \%$ RDF. *For each parameter, different small letters in the column indicates statistical differences among the treatment means $(\mathrm{p}=0.05)$ according to LSD test.

par with $\mathrm{F}_{5}$, i.e. $111.38 \mathrm{~kg} \mathrm{ha}^{-1}$. The sole application of SS produced an increase in the available nitrogen in the soil as compared to the control.

The data (Table 3 ) indicated that the available phosphorus in the soil was significantly reduced to 13.6 and $18.4 \%$ with treatments $I_{2}$ and $I_{3}$ as compared to $I_{1}$, respectively. However, treatments $\mathrm{I}_{2}$ and $\mathrm{I}_{3}$ were found to be statistically similar. The application of SS increased the available phosphorus in the soil. But significantly highest $\mathrm{P}$ was obtained with $\mathrm{F}_{4}$, i.e. $20.81 \mathrm{~kg} \mathrm{ha}^{-1}$; being at par with $\mathrm{F}_{3}$, i.e. $19.22 \mathrm{~kg} \mathrm{ha}^{-1}$ followed by $\mathrm{F}_{5}\left(17.73 \mathrm{~kg} \mathrm{ha}^{-1}\right), \mathrm{F}_{2}$, and $\mathrm{F}_{1}$. Available phosphorus in the soil was significantly increased with the application of SS alone in comparison with the control.

Based on the pooled mean data over a two-year period (Table 3), it was observed that the available potassium in the soil was significantly increased with saline irrigation. The highest value for available potassium in the soil was obtained with $\mathrm{I}_{3}$ (349.39 kg ha-1) which was statistically at par with $\mathrm{I}_{2}\left(332.34 \mathrm{~kg} \mathrm{ha}^{-1}\right)$ and the lowest value was obtained with $\mathrm{I}_{1}\left(292.48 \mathrm{~kg} \mathrm{ha}^{-1}\right)$. A significantly higher value for available potassium was obtained with $\mathrm{F}_{4}$, i.e. 344.98 $\mathrm{kg} \mathrm{ha}^{-1}$ being at par with $\mathrm{F}_{3}\left(333.36 \mathrm{~kg} \mathrm{ha}^{-1}\right)$ and $\mathrm{F}_{5}(324.76$ $\mathrm{kg} \mathrm{ha}^{-1}$ ) over RDF and control treatments among the various fertilizer treatments.

It was observed that microbial biomass carbon (MBC) in the soil was significantly reduced with the increasing salinity levels of irrigation water at each growth stages of pearl millet and wheat crops (Fig. 2). However, treatments with $\mathrm{I}_{2}$ and $\mathrm{I}_{3}$ resulted in a $30.86,50.25 ; 31.67,48.78$ and $31.13,49.69 \%$ reduction at the time of sowing, 35 DAS, and harvest of pearl millet crop, respectively; and 32.14, $51.03 ; 32.63,48.76$ and $33.45,50.61 \%$ reduction at the time of sowing, $75 \mathrm{DAS}$, and at the harvest time of the wheat crop respectively as compared to $\mathrm{I}_{1}$. Among the various fertilizer treatments, $\mathrm{F}_{4}$ produced the highest soil MBC at each growth stages of both crops which was statistically on a par with $\mathrm{F}_{3}$. The integrated use of SS $\left(5 \mathrm{tha}^{-1}\right)$ and $75 \%$ RDF resulted in a significant increase in soil microbial biomass carbon as compared to RDF and control treatments. Irrespective of salinity levels and sewage sludge effects, a higher soil MBC was recorded at 35 DAS (flowering stage) and 75 DAS (flowering stage) of pearl millet and wheat crops followed by harvesting and sowing time, respectively (Fig. 2).

The data pertaining (Fig. 3) to soil dehydrogenase activity indicated that dehydrogenase activity significantly decreased with the gradually increasing levels of saline water irrigation. Irrespective of the application of SS and saline water irrigation, dehydrogenase activity in the soil increased from the sowing time period to 35 DAS for pearl millet and to 75 DAS for wheat and then decreased thereafter up to the harvest time period. For both crops, maximum dehydrogenase activity was however recorded with $I_{1}$ regardless of the crop growth stages. Soil dehydrogenase activity was significantly reduced with the increasing salinity levels of the irrigation water. Among the fertilizer treatments, a significantly higher activity was recorded with $\mathrm{F}_{4}$ followed by $\mathrm{F}_{3}, \mathrm{~F}_{2}, \mathrm{~F}_{5}$, and $\mathrm{F}_{1} . \mathrm{F}_{4}$ treatment produced a significantly higher enzyme activity as compared to the sole application of RDF. Treatment $\mathrm{F}_{4}$ attained highest dehydrogenase activity, i.e., 27.17, 40.68 and 30.58; 30.04, 


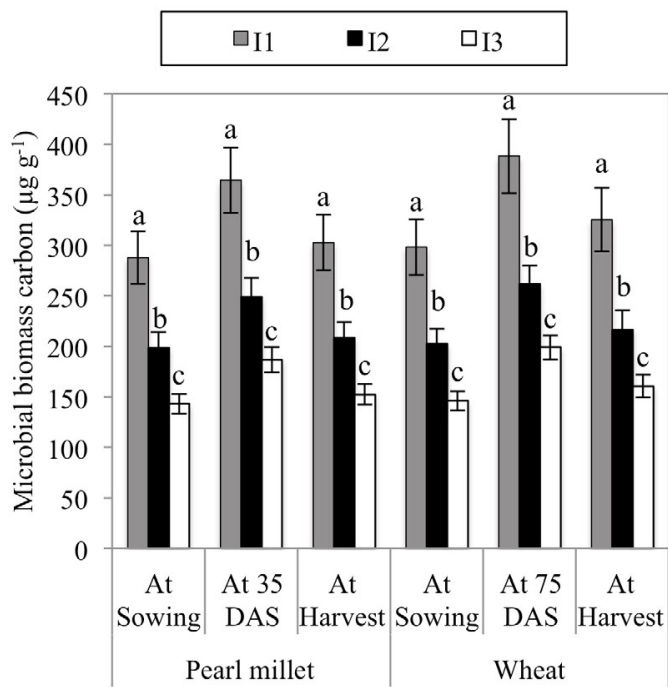

\begin{tabular}{|lllll|}
\hline$\square_{\mathrm{F} 1}$ & $\boldsymbol{口}_{\mathrm{F} 2}$ & $\square_{\mathrm{F} 3}$ & $\square_{\mathrm{F} 4}$ & $\square_{\mathrm{F} 5}$ \\
\hline
\end{tabular}

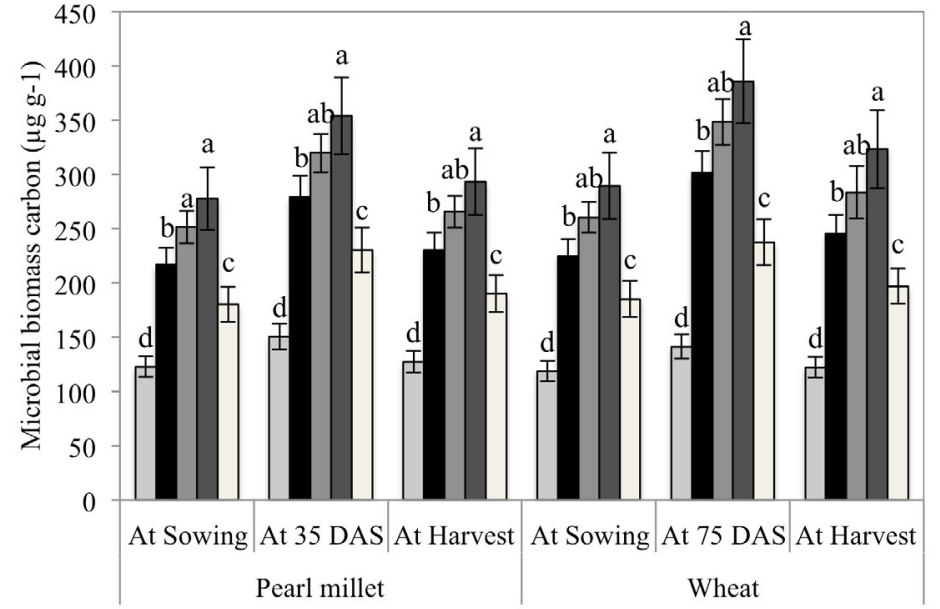

Fig. 2. Effect of a) irrigation-induced salinity and b) sewage sludge application on soil microbial biomass carbon $\left(\mu \mathrm{g} \mathrm{g}^{-1}\right)$ at different growth stages of pearl millet and wheat crops (Pooled mean data of two years; 2017-19); Error bars represent the standard error of the treatment means; For each parameter, different small letters in the column indicate statistical differences among the treatment means $(\mathrm{p}=0.05)$ according to the LSD test. Note: $\mathrm{I}_{1}-$ Canal; $\mathrm{I}_{2}-8 \mathrm{dS} \mathrm{m}^{-1} \mathrm{EC}$ saline water and $\mathrm{I}_{3}-10 \mathrm{dS} \mathrm{m}^{-1} \mathrm{EC}$ saline water; $\mathrm{F}_{1}-$ absolute control (no fertilizer); $\mathrm{F}_{2}-\mathrm{SS}(5 \mathrm{t} / \mathrm{ha}) ; \mathrm{F}_{3}-\mathrm{SS}\left(5 \mathrm{tha}^{-1}\right)+50 \% \mathrm{RDF} ; \mathrm{F}_{4}-\mathrm{SS}\left(5 \mathrm{t} \mathrm{ha}^{-1}\right)+75 \% \mathrm{RDF}$ and $\mathrm{F}_{5}-100 \% \mathrm{RDF}$.

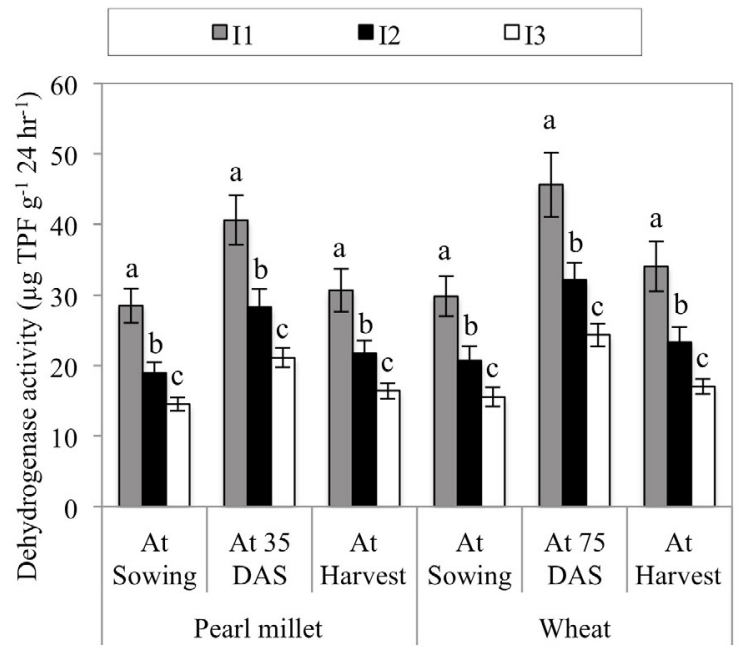

b

\begin{tabular}{|lllll|}
\hline$\square_{\mathrm{F} 1}$ & $\boldsymbol{口}_{\mathrm{F} 2}$ & $\mathbf{v F}_{3}$ & $\square_{\mathrm{F} 4}$ & $\square_{\mathrm{F} 5}$ \\
\hline
\end{tabular}

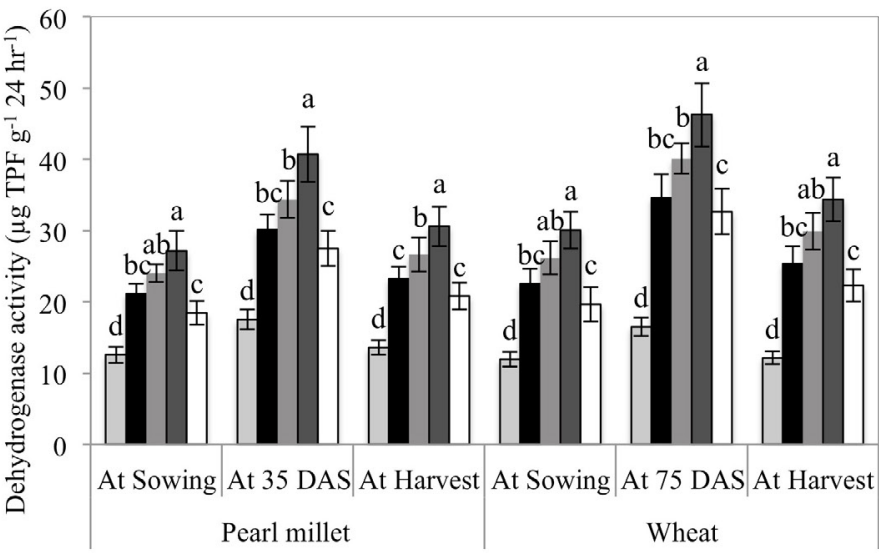

Fig. 3. Effect of a) irrigation-induced salinity and b) sewage sludge application on soil dehydrogenase activity $\left(\mu \mathrm{g} \mathrm{TPF} \mathrm{g}{ }^{-1} 24 \mathrm{~h}^{-1}\right)$ at different growth stages of pearl millet and wheat crops (Pooled mean data of two years; 2017-19); Error bars represent the standard error of the treatment means; For each parameter, different small letters in the column indicate statistical differences among the treatment means $(p=0.05)$ according to the LSD test. Explanations as in Fig. 2.

46.25 and $34.37 \mu \mathrm{g}$ TPF g ${ }^{-1} 24 \mathrm{~h}^{-1}$ at the sowing, flowering (reproduction), and harvesting times of pearl millet and wheat crops, respectively. The direct and residual effect of SS increased dehydrogenase activity in wheat and pearl millet crops at each crop growth stage as compared to the control.

It was noted that the application of saline water irrigation significantly reduced alkaline phosphatase activity in the soil (Fig. 4). Treatment $I_{2}$ and $I_{3}$ caused a significant reduction in soil alkaline phosphatase activity, i.e. 21.76, $37.45 ; 25.17,36.87$ and $21.87,37.84 \%$ at the sowing, 35
DAS and harvest time of the pearl millet crop, respectively; $20.93,37.01 ; 23.68,36.14$ and $22.41,38.29 \%$ in the wheat crop at sowing, 75 DAS and harvesting time, respectively over the $I_{1}$ treatment. Among the various treatments, SS application alone or in combination with inorganic fertilizers for the pearl millet-wheat cropping sequence resulted in a significantly increased soil alkaline phosphatase activity in comparison with the RDF and absolute control treatments. However, a significantly higher alkaline phosphatase activity was recorded with $\mathrm{F}_{4}$ in pearl millet (Fig. 4), i.e. 66.29, 76.74, and 69.40 $\mu \mathrm{g} \mathrm{PNP} \mathrm{g} \mathrm{g}^{-1} \mathrm{~h}^{-1}$ at 


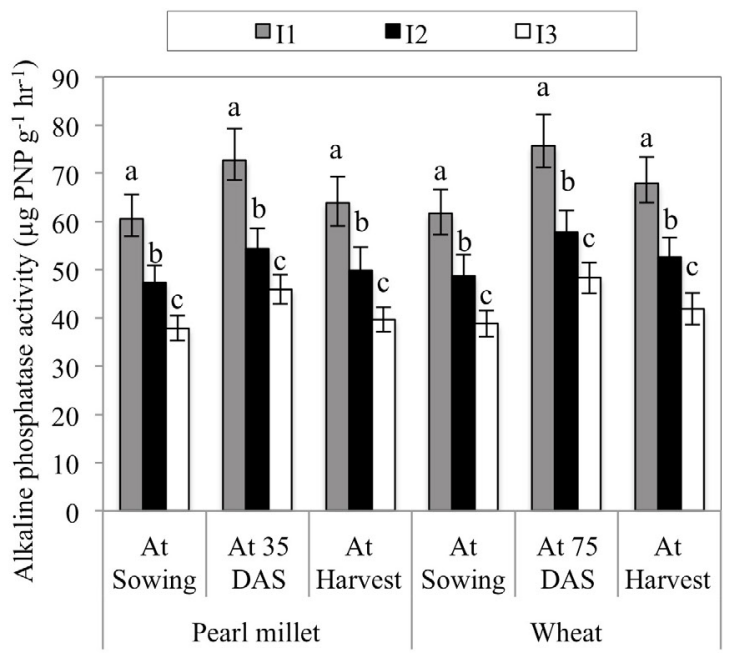

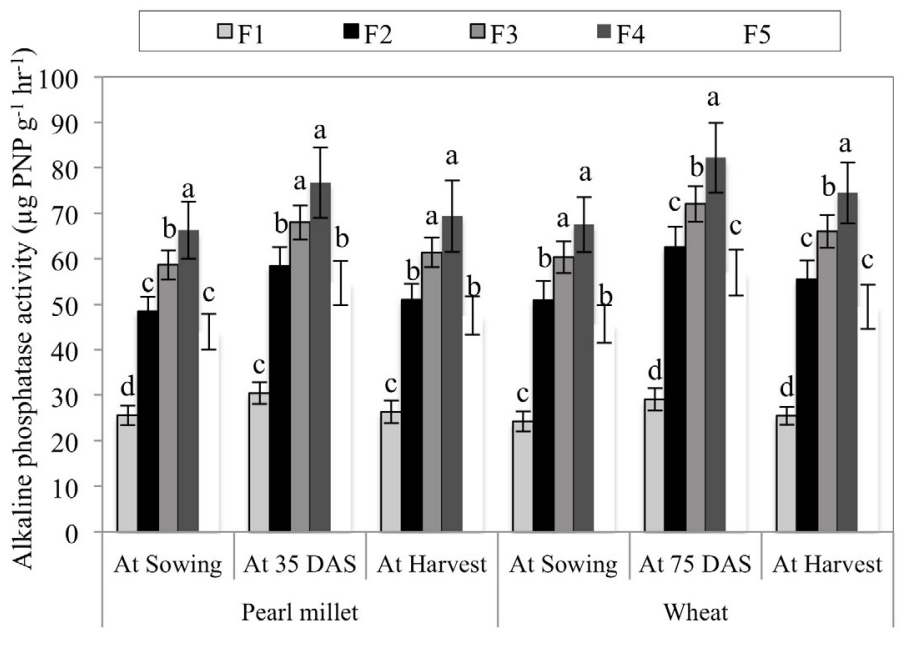

Fig. 4. Effect of a) irrigation-induced salinity and b) sewage sludge application on soil alkaline phosphatase activity $\left(\mu \mathrm{PNP} \mathrm{g}^{-1} \mathrm{~h}^{-1}\right)$ at different growth stages of the pearl millet and wheat crops (Pooled mean data of two years; 2017-19). Error bars represent the standard error of the treatment means; For each parameter, different small letters in the column indicate statistical differences among the treatment means $(p=0.05)$ according to the LSD test. Explanations as in Fig. 2.

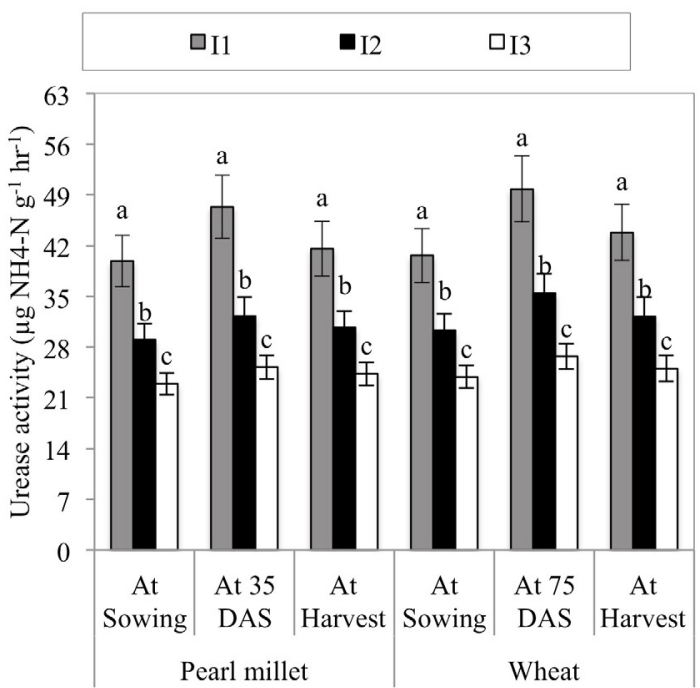

$\begin{array}{lllll}\square_{\mathrm{F} 1} & \boldsymbol{\sigma}_{\mathrm{F} 2} & \square_{\mathrm{F}} 3 & \square_{\mathrm{F}} 4 & \square_{\mathrm{F}}\end{array}$

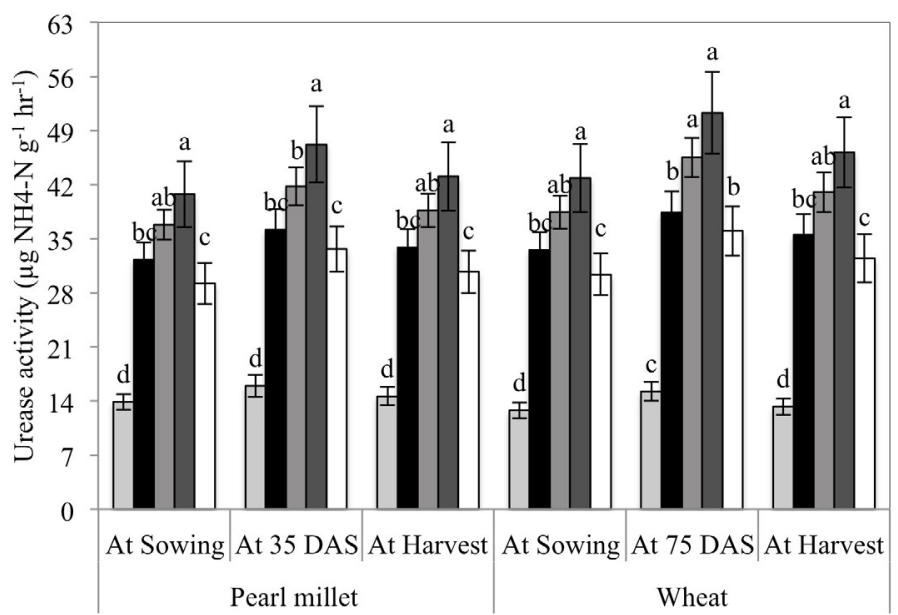

Fig. 5. Effect of a) irrigation-induced salinity and b) sewage sludge application on soil urease activity $\left(\mu \mathrm{g} \mathrm{NH}_{4}{ }^{+}-\mathrm{N} \mathrm{g}^{-1} \mathrm{~h}^{-1}\right)$ at different growth stages of pearl millet and wheat crops (Pooled mean data of two years; 2017-19). Error bars represent the standard error of the treatment means; For each parameter, different small letters in the column indicate statistical differences among the treatment means $\mathrm{p}=0.05$ ) according to the LSD test. Explanations as in Fig. 2.

the sowing, 35 DAS and harvest time period, respectively and as well as in wheat, i.e. $67.53,82.24$, and $74.47 \mu \mathrm{g}$ PNP g ${ }^{-1} \mathrm{~h}^{-1}$ at the sowing, 75 DAS and harvest time period, respectively, among the various fertilizer treatments and, the lowest activity was recorded in the control treatment where no fertilizer was added.

The data (Fig. 5) indicated that urease activity was affected to a significant extent by the application of both saline irrigation and sewage sludge. Treatments $\mathrm{I}_{2}$ and $\mathrm{I}_{3}$ significantly decreased the urease activity in soil compared to $I_{1}$. The maximum urease activity during crop growth stages, i.e. during the sowing, $35 / 75 \mathrm{DAS}$, and harvest time periods of pearl millet $\left(39.88,47.37\right.$, and $41.58 \mu \mathrm{g} \mathrm{NH}_{4}-\mathrm{N}$ $\mathrm{g}^{-1} \mathrm{~h}^{-1}$, respectively) as well as wheat $(40.63,49.82$ and $43.83 \mu \mathrm{g} \mathrm{NH}_{4}-\mathrm{N} \mathrm{g}^{-1} \mathrm{~h}^{-1}$, respectively) was recorded with the $\mathrm{I}_{1}$ treatment whereas the minimum values were observed in plots receiving $10 \mathrm{dS} \mathrm{m}^{-1} \mathrm{EC}$ of saline irrigation. A significant increase in urease activity was observed at each crop growth stages due to the direct and residual effects of SS application in both wheat and pearl millet, respectively. A significantly higher urease activity was observed with the $\mathrm{F}_{4}$ treatment irrespective of saline irrigation and the crop growth stages. Also, the results produced by the sole application of SS were at par with the RDF treatment. Urease 
activity was recorded to be significantly higher at 35 DAS and 75 DAS for pearl millet and wheat crops, respectively, followed by the harvesting and sowing time periods.

\section{DISCUSSION}

Soil $\mathrm{pH}$ did not decrease to a significant extent while soil EC was significantly increased with the application of saline irrigation (Table 3 ). Similar results were reported by Meena et al. (2016). However, the decrease in $\mathrm{pH}$ may be due to increased electrolyte concentration in the soil solution due to the continuous use of saline water irrigation which compressed the diffuse double layer on to the clay surface. $\mathrm{H}^{+}$ions will be free to move from the clay surface to the soil solution and lower its $\mathrm{pH}$ (Usman, 2015). Due to the prolonged use of saline water, the salt concentration accumulated in the soil, which enhanced soil EC (Singh et al. 2018a).

Soil organic carbon is a key chain to soil fertility status and its potential productivity. The decrease in soil organic carbon with irrigation-induced salinity (Table 3 ) occurred due to the reduced ability of soil to sustain organic matter and this in turn was due to reduced microbial activity (Iwai et al., 2012). As reported by Ghollarata and Raiesi (2007), the reduced osmotic potential of the soil solution restricted the ability of microorganisms to utilize the added substrate. The decrease in organic carbon under saline conditions was also due to reduced crop growth and accordingly, reduced carbon input to the soil (Egamberdieva et al., 2010). The combined use of SS and mineral fertilizers may have added a large amount of organic matter to the soil (Sharma and Dhaliwal, 2019). The increase in organic carbon may be due to the significant addition of organic manure which encouraged microbe growth and activity as well as improved root growth (Eid et al., 2019), resulting in the increased production of biomass, crop stubble, and residues. The potential decomposition of these materials may have contributed to the increased carbon content of the soil (Meena et al., 2016). Since the organic matter content in SS was high, its application facilitated the considerably higher organic carbon content in the SS amended plots (Singh and Agrawal, 2010).

The increasing salinity levels of the irrigation water significantly reduced the available $\mathrm{N}$ and $\mathrm{P}$ in the soil while the available $\mathrm{K}$ was found to increase (Table 3). This reduction in available $\mathrm{N}$ may be ascribed to a decrease in the rate of nitrification of ammonium ions due to salinity and the direct effects of chloride ions on bacterial activity. In the transformation of urea in the soil, the production of $\mathrm{NH}_{4}^{+}$was not inhibited but nitrification was severely inhibited thereby reducing the production of $\mathrm{NO}_{3}^{-}-\mathrm{N}$ in the soils (Singh et al., 2018a). The decrease in available $\mathrm{P}$ in the soil may be ascribed to an increase in the solubility of calcium from native $\mathrm{CaCO}_{3}$ in the presence of $\mathrm{NaCl}$ which increases the precipitation of phosphorus in the soil
(Kumawat et al., 2011). Another reason for this reduction may be the increase in the ionic strength of the soil thereby reducing the retention of $\mathrm{P}$ (Awad et al., 1990). However, the increase in available $\mathrm{K}$ may be due to the addition of potassium through irrigation water (Sekhon et al., 2019).

Among the various fertilizer treatments, the significantly increase in available $\mathrm{N}, \mathrm{P}$, and $\mathrm{K}$ in the soil were attained with the $\mathrm{F}_{4}$ treatment (Table 3 ). This may be attributed to the enhanced mineralization of manures in the presence of the inorganic fertilizers which leads to the enrichment of nutrients in the soil native pool, and also increases its efficiency by liberating nutrients gradually (Sharma and Dhaliwal, 2019). The increase in available $\mathrm{N}$ may be attributed to the increased microbial population involved in the conversion of organically bound $\mathrm{N}$ into the inorganic form (Meena et al., 2016). The application of SS enhanced the solubilization of the insoluble organic $\mathrm{P}$ fraction through the release of various organic acids in soils upon decomposition thus resulting in a significant improvement in the $\mathrm{P}$ status of the soil (Singh et al., 2018b). The present study shows an ensuing build-up of potassium in the soil with SS application which may be attributed to reduced $\mathrm{K}$ fixation and the release of $\mathrm{K}$ from the association of organic matter from SS with clay particles (Angin et al., 2016). Our results suggest that the integrated use of SS and inorganic fertilizers is better suited to making nutrients available in soil than inorganic fertilizer only.

Soil microbial activity like MBC and soil enzymes are a key indicator of soil biological health (Borase et al., 2020). In the present study, irrigation water-induced salinity had an adverse effect on soil microbial activities (Yuan et al., 2007; Muscolo et al., 2011; Singh et al., 2018a) thereby reducing microbial biomass carbon (Fig. 2) and the enzyme activities in the soil at different crop growth stages (Figs 3-5). Yuan et al. (2007) reported a significant exponential relationship between EC and MBC. The decrease in $\mathrm{MBC}$ was due to the toxic effects of $\mathrm{Na}^{+}$and $\mathrm{Cl}^{-}$on soil microflora (Sardinha et al., 2003) it was also due to osmotic effects (Rietz and Hayanes, 2003). Under salt stress conditions, more carbon is consumed via respiration instead of being utilized for microbial growth and humus formation (Singh, 2016). Shah and Shah (2011) recorded a decrease in average soil microbial biomass $\mathrm{C}$ from $391 \mathrm{mg} \mathrm{kg}^{-1}$ in soils of EC $<4.0 \mathrm{dS} \mathrm{m}^{-1}$ to $209 \mathrm{mg} \mathrm{kg}^{-1}$ in soils with an EC of $>12 \mathrm{dS} \mathrm{m}^{-1}$ that may be coupled with increasing microbial stress under saline conditions and a higher consumption of $\mathrm{C}$ to maintain their cell structure that resulted in the drying and lysis of cells (Egamberdieva et al., 2010). Nevertheless, it would be very interesting to know how salinity affects soil enzymes or what factors are accountable for their disrupted activities. Salinity has a direct effect on microbial enzyme production and their structural changes due to ionic movement and lower OM availability (Yao et al., 2009; Singh, 2016). Rietz and Haynes (2003) also reported reduced microbial enzyme activity under 
irrigation-induced salinity conditions due to a reduction in substrate availability and microbial growth. Singh et al. (2018a) also observed that the application of saline water irrigation (EC - 9 and $12 \mathrm{dS} \mathrm{m}^{-1}$ ) decreased dehydrogenase activity by 35.8 and $54.8 \%$ compared to using water of a good quality, respectively. The reduction in soil enzyme activity under salt stress may be due to: osmotic stress, a salting-out effect that modified the ionic confirmation of the active centre of the enzymes and specific ion toxicities which caused a nutritional imbalance in microbial growth and enzyme synthesis (Zahir et al., 2001). Many of the enzymes are extracellular and form stable complexes with organic and mineral colloids. In the present study, the increase in soil EC due to the prolonged use of saline water irrigation disperses the clay resulting in uncovered stable enzymes that are more vulnerable to denaturalization through proteolysis (Nannipieri et al., 2012). The decrease in soil osmotic potential, which decreased protein solubility by dehydration and subsequently altered the binding affinity of the enzyme protein, may only explain one such result (Siddikee et al., 2011).

The present study exhibited significantly enhanced microbial biomass carbon (Fig. 2) and enzyme activities (dehydrogenase, alkaline phosphatases, and urease activity) in the soil (Figs 3-5) with $\mathrm{F}_{4}$, among various fertilizer treatments. The increased microbial activities in the soil may be attributed to the addition of substrate/nutrients through the addition of SS (Jezierska-Tys and Frąc, 2009) which might have synthesized enzymes and increased the microbial population in the soil (Meena et al., 2016). Therefore, MBC and enzyme activity was higher in SS amended treatments as compared to the control and RDF treatments. Soil microbial biomass is the biological aspect of SOM and soil enzymes play a vital role in the soil's biochemical activity (Islam and Borthakur, 2016). The increase in MBC largely depends on the amount of readily metabolized carbon which is obtained by the addition of organic amendments (Tejada et al., 2006). Meena et al. (2016) recorded a $42 \%$ higher MBC as well as other enzyme activity with the addition of municipal solid waste compost (MSWC)@ $8 \mathrm{t} \mathrm{ha}^{-1}+50 \%$ $\mathrm{RDF}$ as compared to the control. The microbial behaviour of the soil depends on the amount of organic matter present in the soil and is described by the dehydrogenase activity that is involved in the biological oxidation of SOM (Maurya et al., 2011). According to Sharma and Dhaliwal (2019), soil enzyme activities (dehydrogenase, alkaline phosphatases, and urease activity) were recorded significantly higher with the integrated application of sewage sludge and inorganic fertilizers because of the widespread availability of organic substrate which triggers microbial activity. Hamuda and Ligetvari (2011) noted that a higher value of enzyme activity in soil was observed in the SS treated plots and as a consequence the proportion of $\mathrm{MBC}$ increased, this may be explained by the higher amount of organic matter in the soil (Nannipieri, 1994) and by the presence of $\mathrm{N}$ source serving as a source of nutrients for soil biota (Pascual et $a l ., 2007)$. In the present study, SS addition didn't cause any adverse effect on microbial activity despite the presence of potentially toxic heavy metals because the SS used for the experiment was domestic in origin and contained lower amounts of heavy metals as per the standard guidelines of CPCB. However, the enhanced urease activity in pearl millet and wheat crops may be due to the presence of Ni content in the sewage sludge (Patel and Patra, 2014), since the enzyme is metal-dependent (Melo et al., 2007) if the other metals are not capable of inactivating the enzyme. Thus, these findings lead us to the hypothesis that domestic SS $\left(5 \mathrm{t} \mathrm{ha}^{-1}\right)$ can be safely disposed of in agricultural soils. Many previous studies have shown that soil enzyme activity is revived by the incorporation of SS (Medina et al., 2015; Skowrońska et al., 2020; Curci et al., 2020), this is due to the substantial accumulation of nutrients, organic matter, and the increasing microbial population, applied with SS.

Soil microbial activity was found to be higher in the Rabi season as compared to Kharif because the SS was applied in the Rabi season only. Temporal variations may be another explanation (Akmal et al., 2012). Seasonal changes in soil urease activity were reported by Sardans et al. (2008) and found to be higher in winter when the soil temperature was low as compared to summer. Sardans and Penuclas (2005) found a clear positive correlation between soil dehydrogenase and alkaline phosphatase activity with soil water availability.

The growth stages, i.e. 35 and 75 DAS were assumed to be the flowering stages in pearl millet (Maiti and Bidinger, 1981) and wheat crop (Zadoks et al., 1974). However, soil MBC and other enzyme activities peaked at the flowering stages in both crops. This may be due to vigorous growth during the 35 and 75 DAS in pearl millet and wheat, respectively, and also due to the release of root exudation, secretions, mucigel, mucilage, etc. which is more evident during this period in the rhizosphere due to their long residence time (Rakshit et al., 2012; Dotaniya et al., 2014). Also, root exudates are carbon compounds like sugar, amines, etc. which act as a substrate for microorganisms in the soil (Nihorimbere et al., 2011).

\section{CONCLUSIONS}

1. It may be concluded from two years of study that the use of saline water in the pearl millet-wheat cropping system results in salt accumulation in sandy loam textured soil.

2. Soil organic carbon, and available $\mathrm{N}$, and $\mathrm{P}$ were reduced under saline condition whereas, soil electrical conductivity and available $\mathrm{K}$ were increased with increasing salinity levels. 
3. The significantly higher concentration of salts with a corresponding decrease in the supply of organic carbon and $\mathrm{N}$ availability shows that salinity has an adverse effect on microbial biomass carbon and enzyme activities in the soil.

4. The combined application of sewage sludge with mineral fertilizers enhanced the chemical and biological properties of soils. However, sewage sludge application did not affect soil $\mathrm{pH}$ and electrical conductivity statistically.

5. Soil microbial biomass carbon and enzyme activities were higher at 35 DAS in pearl millet crop and at 75 DAS in wheat crop followed by the harvest and sowing time periods which may be due to the release of certain chemicals, root exudates, etc.

6. Sewage sludge is well suited for agricultural use due to its nutritious value. The use of sewage sludge in farming not only solves the problem of its disposal but also improves soil biological health by improving its chemical and biological properties. From the present study, we may conclude that the integrated application of sewage sludge $\left(5 \mathrm{t} \mathrm{ha}^{-1}\right)$ and mineral fertilizers $(75 \%$ recommended dose of fertilizer) may boost microbial activity, and the build-up, and maintenance of the nutrient status of soil.

Conflict of interest: The authors declare no conflict of interest.

\section{REFERENCES}

Ahmed H.K., Fawy H.A., and Abdel-Hady E.S., 2010. Study of sewage sludge use in agriculture and its effect on plant and soil. Agriculture and Biology J. North America, 1(5), 10441049. https://doi.org/10.5251/abjna.2010.1.5.1044.1049

Akmal M., Altaf M.S., Hayat R., Hassan F.U., and Islam M., 2012. Temporal changes in soil urease, alkaline phosphatase and dehydrogenase activity in rainfed wheat field of Pakistan. J. Animal Plant Sci., 22(2), 457-462.

Angin I., Aslantas R., Gunes A., Kose M., and Ozkan G., 2016. Effects of sewage sludge amendment on some soil properties, growth, yield and nutrient content of raspberry (Rubus idaeus L.). Erwerbs-obstbau, 59(2), 93-99. https://doi. org/10.1007/s10341-016-0303-9

Antil R.S., Singh A., and Dahiya S.S., 2002. Practical Mannual for Soil and Plant Analysis. Department of Soil Science, CCS Haryana Agricultural University, Hisar - 125004. https://doi.org/10.22438/jeb/40/1/mrn-887

Aranyos J.T., Tomocsik A., Makádi M., Mészáros J., and Blasko L., 2016. Changes in physical properties of sandy soil after long-term compost treatment. Int. Agrophys., 30(3), 269-274. https://doi.org/10.1515/intag-2016-0003

Awad A.S., Edwards D.G., and Campell L.C., 1990. Phosphorus enhancement of salt tolerance of tomato. Crop Science, 30, 123-128. https://doi.org/10.2135/cropsci1990.0011183x00 $3000010028 x$

Bhat M.A., Grewal M.S., Dinesh, Singh I., and Grewal K.S., 2017. Geoinformatics for quantifying salt affected soils in Gohana, Haryana using soil techniques. Int. J. Current Microbiol. Appl. Sci., 6(9), 835-858. https://doi. org/10.20546/ijcmas.2017.609.103
Borase D.N., Nath C.P., Hazra K.K., Senthilkumar M., Singh S.S., Praharaj C.S., Singh U., and Kumar N., 2020. Long-term impact of diversified crop rotations and nutrient management practices on soil microbial functions and soil enzymes activity. Ecological Indicators, 114, 106322.

https://doi.org/10.1016/j.ecolind.2020.106322

Bourioug M., Mazzitelli J.Y., Marty P., Budzinski H., Aleya L., Bonnafe E., and Geret F., 2017. Assessment of Lemna minor (duckweed) and Corbicula fluminea (freshwater clam) as potential indicators of contaminated aquatic ecosystems: responses to presence of psychoactive drug mixtures. Environ. Sci. Pollut. Res., https://doi.org/10.1007/ s11356-017-8447-1

Chesnin L. and Yien C.H., 1950. Turbidimetric determination of available sulphates. Soil Sci. Soc. Am. J., 15, 149-151. https://doi.org/10.2136/sssaj1951.036159950015000c0032x

CPCB, 2006. Status of sewage treatment in India November 2005 status report CUPS/61/2005-06

Curci M., Lavecchia A., Cucci G., Lacolla G., De Corato U., and Crecchio C., 2020. Short-term effects of sewage sludge compost amendment on semi-arid soil. Soil Systems, 4(3), 48. https://doi.org/10.3390/soilsystems4030048

Datta K.K. and De Jong C., 2002. Adverse effect of waterlogging and soil salinity on crop and land productivity in northwest region of Haryana, India. Agricultural Water Manag., 57(3), 223-238. https://doi.org/10.1016/s0378-3774(02)00058-6

Dotaniya M.L., Kushwah S.K., Rajendiran S., Coumar M.V., Kundu S., and Rao A.S., 2014. Rhizosphere effect of kharif crops on phosphatases and dehydrogenase activities in a Typic Haplustert. National Academy Science Letters, 37(2), 103-106. https://doi.org/10.1007/s40009-013-0205-4

Egamberdieva D., Renella G., Wirth S., and Islam R., 2010. Secondary salinity effects on soil microbial biomass. Biology Fertility Soils, 46, 445-449. https://doi.org/10.1007/s00374-010-0452-1

Eid E.M., Alrumman S.A., El-Bebany A.F., Fawy K.F., Taher M.A., Hesham A.E.L., El-Shaboury G.A., and Ahmed M.T., 2019. Evaluation of the potential of sewage sludge as a valuable fertilizer for wheat crop. Environ. Sci. Poll. Res., 26(1), 392-401. https://doi.org/10.1007/s11356-018-3617-3

Ghollarata M. and Raiesi F., 2007. The adverse effects of soil salinization on the growth of Trifolium alexandrinum L. and associated microbial and biochemical properties in a soil from Iran. Soil Biol. Biochem., 39, 1699-1702. https://doi.org/10.1016/j.soilbio.2007.01.024

Hamuda H.B. and Ligetvari F., 2011. Impacts of municipal sewage sludge on dynamics of organic matter and biological activities in clay loam brown forest soil. J. Residuals Sci. Technol., 8(4), 143-149.

Huang W., Liu J., Zhou G., Zhang D., and Deng Q., 2011. Effects of precipitation on soil acid phosphatase activity in three succession forests in Southern China. Biogeosciences, 8, 1901-1910. https://doi.org/10.5194/bg-8-1901-2011

Iwai C.B., Oo A.N., and Topark-ngarm B., 2012. Soil property and microbial activity in natural salt affected soils in an alternating wet-dry tropical climate. Geoderma, 189, 144152. https://doi.org/10.1016/j.geoderma.2012.05.001 
Islam N.F. and Borthakur 2016. Effect of different growth stages on rice crop on soil microbial and enzyme activities. Tropical Plant Research, 3 (1), 40-47.

Jezierska-Tys S. and Frąc M., 2009. Impact of dairy sewage sludge on enzymatic activity and inorganic nitrogen concentrations in the soils. Int. Agrophys., 23(1), 31-37.

Jingjing S., Jiaheng M., Xiaoying W., Cheng W., and Jun Y., 2015. Microorganism quality and enzyme activities in wheat field subjected to different nitrogen fertilizer rates. Open Biotechnol. J., 9, 204-208. https://doi.org/10.2174/1874070701509010204

Kumar V., Kumar D., and Kumar P., 2007. Declining water table scenario in Haryana - A review. Water and Energy International, 64(2), 32-34.

Kumawat R.M., Pathan A.R.K., and Yadav K.K., 2011. Effect of FYM and phosphorus on soil properties and nutrient content of fenugreek under saline water irrigation. Ecology, Environment and Conservation, 17(4), 711-716.

Leogrande R. and Vitti C., 2018. Use of organic amendments to reclaim saline and sodic soils: a review. Arid Land Research and Management, 33(1), 1-21. https://doi.org/10.1080/15324982.2018.1498038

Maiti R.K. and Bidinger F.R., 1981. Growth and development of the pearl millet plant Research Bulletin No 6. Patancheru, A.P., India, International Crops Research Institute for the Semi-Arid Tropics.

https://doi.org/10.21475/ajcs.18.12.12.p1138

Maurya B.R., Singh V., and Dhyani P.P., 2011. Enzymatic activities and microbial population in agric-soils of Almora District of Central Himalaya as influenced by altitudes. Int. J. Soil Sci., 6, 238-248.

https://doi.org/10.3923/ijss.2011.238.248

McGrath S.P., Zhao F.J., Dunham S.J., Crosland A.R., and Coleman K., 2000. Long term changes in extractability and bioavailability of zinc and cadmium after sludge application. J. Environmental Quality, 29, 875-883. https://doi.org/10.2134/jeq2000.00472425002900030025x

Medina J., Monreal C., Barea J.M., Arriagada C., Borie F., and Cornejo P., 2015. Crop residue stabilization and application to agricultural and degraded soils: a review. Waste Management, 42, 41-54.

https://doi.org/10.1016/j.wasman.2015.04.002

Meena M.D., Joshi P.K., Jat H.S., Chinchmalatpure A.R., Narjary B., Sheoran P., and Sharma D.K., 2016. Changes in biological and chemical properties of saline soil amended with municipal solid waste compost and chemical fertilizers in a mustard-pearl millet cropping system. Catena, 140, 1-8.

https://doi.org/10.1016/j.catena.2016.01.009

Meena M.D., Narjary B., Sheoran P., Jat H.S., Joshi P.K., Chinchmalatpure A.R., Yadav G., Yadav R.K., and Meena M.K., 2018. Changes of phosphorus fractions in saline soil amended with municipal solid waste compost and mineral fertilizer in a mustard-pearl millet cropping system. Catena, 160, 32-40.

https://doi.org/10.1016/j.catena.2017.09.002
Melo W.J., Aguiar P.S., de Melo G.M., Peruca M., and Valeria P., 2007. Nickel in a tropical soil treated with sewage sludge and cropped with maize in a long-term field study. Soil Biol. Biochemistry, 39, 1341-1347. https://doi.org/10.1016/j.soilbio.2006.12.010

Muscolo A., Mallamaci C., Panuccio M.R., Caputo R., and De Pascale S., 2011. Effect of long-term irrigation water salinity on soil properties and microbial biomass. Ecological Questions, 14, 77-79. https://doi.org/10.12775/v10090-011-0022-7

Nannipieri P., 1994. The potential use of soil enzymes as indicators of productivity, sustainability and pollution. pp. 238-244. In: Soil Biota Management in Sustainable Farming Systems (Eds C.E. Pankhurst, B.M. Double, V.V.S.R. Gupta, and P.R. Grace). CSIRO, East Melbourne.

Nannipieri P., Giagnoni L., Renella G., Puglisi E., Ceccanti B., Masciandaro G., Fornasier F., Moscatelli M.C., and Marinari S., 2012. Soil enzymology: classical and molecular approaches. Biol. Fertility Soils, 48, 743-762. https:// doi.org/10.1007/s00374-012-0723-0

Nihorimbere V., Ongena M., Smargiassi M., and Thonart P., 2011. Beneficial effect of the rhizosphere microbial community for plant growth and health. Biotechnology, Agronomy, Soci. Environ., 15(2), 327-337.

Page A.L., Miller R.H., and Keeney D.R., 1982. Methods of Soil Analysis. 2nd Edn., American Society of Agronomy, Madison, USA.

Pascual I., Antolin M.C., Garcia C., Polo A., and Sanchez-Diaz M., 2007. Effect of water deficit on microbial characteristics in soil amended with sewage sludge or inorganic fertilizer under laboratory conditions. Bioresour. Technol., 98, 29-37. https://doi.org/10.1016/j.biortech.2005.11.026

Patel A. and Patra D.D., 2014. Influence of heavy metal rich tannery sludge on soil enzymes vis-a-vis growth of Tagetes minuta, an essential oil bearing crop, Chemosphere, 112, 323-332. https://doi.org/10.1016/j.chemosphere.2014.04.063

Rakshit R., Patra A.K., Pal D., Kumar M., and Singh R., 2012. Effect of elevated $\mathrm{CO}_{2}$ and temperature on nitrogen dynamics and microbial activity during wheat (Triticum aestivum L.) growth on a subtropical inceptisol in India. J. Agronomy Crop Sci., 198(6), 452-465. https://doi.org/10.1111/j.1439-037x.2012.00516.x

Richard L.A., 1954. Diagnosis and improvement of saline and alkaline soils. USDA Handbook Number 60, Washington D.C. Estimation of available phosphorous in soil by extraction with sodium bicarbonate. Circulars USDA. 939.

Rietz D.N. and Haynes R.J., 2003. Effect of irrigation-induced salinity and sodicity on soil microbial activity. Soil Biology Biochemistry, 35, 845-854. https://doi.org/10.1016/s0038-0717(03)00125-1

Sardans J. and Penuelas J., 2005. Drought decreases soil enzyme activity in a Mediterranean Quercus ilex L. forest. Soil Biology Biochemistry, 37, 455-461. https://doi.org/10.1016/j.soilbio.2004.08.004

Sardans J., Penuelas J., and Estiarte M., 2008. Changes in soil enzymes related to $\mathrm{C}$ and $\mathrm{N}$ cycle and in soil $\mathrm{C}$ and $\mathrm{N}$ content under prolonged warming and drought in a Mediterranean shrub land. Appl. Soil Ecol., 39, 223-235. https://doi. org/10.1016/j.apsoil.2007.12.011 
Sardinha M., Müller T., Schmeisky H., and Joergensen R.G., 2003. Microbial performance in soils along a salinity gradient under acidic conditions. Appl. Soil Ecol., 23, 237-244. https://doi.org/10.1016/s0929-1393(03)00027-1

Sekhon K.S., Kaur A., Thaman S., Sidhu A.S., Garg N., Choudhary O.P., Buttar G.S., and Chawla N., 2019. Irrigation water quality and mulching effects on tuber yield and soil properties in potato (Solanum tuberosum L.) under semi-arid conditions of Indian Punjab. Field Crops Res., https://doi.org/10.1016/j.fcr.2019.06.001

Shah S.A. and Shah Z., 2011. Changes in soil microbial characteristics with elevated salinity. Sarhad J. Agric., 27(2), 233-244.

Sharma S. and Dhaliwal S.S., 2019. Effect of sewage sludge and rice straw compost on yield, micronutrient availability and soil quality under rice-wheat system. Communications in Soil Science and Plant Analysis, https://doi.org/10.1080/00 103624.2019.1648489

Sheoran O.P., Tonk D.S., Kaushik L.S., Hasija R.C., and Pannu R.S., 1998. Statistical Software Package for Agricultural Research Workers. Recent Advances in information theory, Statistics \& Computer Applications by Hooda, D.S., Hasija, R.C., Department of Mathematics Statistics, CCS HAU, Hisar (139-143).

Siddikee M.A., Tipayno S.C., Kim K., Chung J.B., and Sa T., 2011. Influence of varying degree of salinity-sodicity stress on enzyme activities and bacterial populations of coastal soils of Yellow Sea, South Korea. J. Microbiol. Biotechnol., 2, 341-346. https://doi.org/10.4014/jmb.1012.12015

Singh P., Choudhary O.P., and Mavi M.S., 2018a. Irrigationinduced salinization effects on soil chemical and biological properties under cotton-wheat rotation in loamy sand soil in Northwest India. J. Indian Soc. Soil Sci., 66(4), 386-391. https://doi.org/10.5958/0974-0228.2018.00048.8

Singh S.K., Kumar M., Singh R.P., Bohra J.S., Srivastva J.P., Singh S.P., and Singh Y.V., 2018b. Conjoint application of organic and inorganic sources of nutrients on yield, nutrient uptake and soil fertility under rice-wheat system. J. Indian Soc. Soil Sci., 66(3), 287-294. https://doi.org/10.5958/0974-0228.2018.00035.x

Singh R.P. and Agrawal M., 2010. Variations in heavy metal accumulation, growth and yield of rice plants grown at different sewage sludge amendment rates. Ecotoxicology and Environment Safety, 73(4), 632-641. https://doi.org/10.1016/j.ecoenv.2010.01.020

Singh K., 2016. Microbial and enzyme activities of saline and sodic soils. Land Degradation and Development, 27(3), 706-718. https://doi.org/10.1002/ldr.2385

Skowrońska M., Bielińska E.J., Szymański K., Futa B., Antonkiewicz J., and Kolodziej B., 2020. An integrated assessment of the long-term impact of municipal sewage sludge on the chemical and biological properties of soil. Catena, 189, 104484. https://doi.org/10.1016/j.catena.2020.104484

Srinivasarao C., Kundu S., Grover M., Manjunath M., Sudhanshu S.K., Patel J.J., Singh S.R., Singh R.P., Patel M.M., Arunachalam A., and Soam S.K., 2018. Effect of long term application of organic and inorganic fertilizers on soil microbial activities in semi-arid and sub-humid rainfed agricultural systems. Tropical Ecology, 59(1).

Tabatabai M.A. and Bremner J.M., 1972. Assay of urease activity in soils. Soil Biology Biochemistry, 4, 479-487. https://doi.org/10.1016/0038-0717(72)90064-8

Tejada M., Garcia C., Gonzalez J.L., and Hernandez M.T., 2006. Organic amendment based on fresh and composted beet vinasse. Soil Sci. Soc. America J., 70, 900-908. https://doi.org/10.2136/sssaj2005.0271

Todd D.K., 1980. Groundwater Hydrology, Second edition, John Wiley and Sons, New York.

Usman A.R.A., 2015. Influence of $\mathrm{NaCl}$ induced salinity and $\mathrm{Cd}$ toxicity on respiration activity and $\mathrm{Cd}$ availability to barley plants in FYM-amended soil. Appl. Environ. Soil Sci., https://doi.org/10.1155/2015/483836

Vance E.D., Broolers P.C., and Jenkinson D.S., 1987. An extraction method for measuring soil microbial biomass carbon. Soil Biology Biochem., 19, 703-707. https://doi.org/10.1016/0038-0717(87)90052-6

Wang J., Wang H., Cao Y., Bai Z., and Qin Q., 2016. Effects of soil and topographic factors on vegetation restoration in opencast coal mine dumps located in a loess area. Scientific Reports, 6(1), 1-11. https://doi.org/10.1038/srep22058

Wang Q.K., Wang S.L., and Liu Y.X., 2008. Responses to $\mathrm{N}$ and $\mathrm{P}$ fertilization in a young Eucalyptus dunnii plantation: Microbial properties, enzyme activities and dissolved organic matter. Applied Soil Ecology, 40, 484-90. https:// doi.org/10.1016/j.apsoil.2008.07.003

Yadav S.S., Tikkoo A., and Singh J.P., 2012. Effect of potassium on pearl millet-wheat Cropping system in coarse textured soils of Southern Haryana. J. Indian Soc. Soil Sci., 60(2), 145-149. https://doi.org/10.5958/0974-0228.2016.00032.3

Yao S., Qin J., Peng X., and Zhang B., 2009. The effect of vegetation on restoration of physical stability of severely degraded soil in China. Ecological Engineering, 35, 723734. https://doi.org/10.1016/j.ecoleng.2008.11.008

Yuan B., Li Z., Liu H., Gao M., and Zhang Y., 2007. Microbial biomass and activity in salt affected soils under arid conditions. Applied Soil Ecology, 35, 319-328. https://doi.org/10.1016/j.apsoil.2006.07.004

Zadoks J.C., Chang T.T., and Konzak C.F., 1974. A decimal code for the growth stages of cereals. Weed Res., 14, 415421. https://doi.org/10.1111/j.1365-3180.1974.tb01084.x

Zahir Z.A., Malik M.A.R., and Arshad M., 2001. Soil enzymes research: a review. Online J. Biol. Sci., 1, 299-307. 